\title{
INFLATIE EN DE FINANCIËLE STRUCTUUR VAN ONDERNEMINGEN. DEEL I')
}

\author{
door Prof. Dr. S. E. de Jong
}

\section{Inleiding}

Een opvallend verschijnsel is de ingrijpende verandering die zich de laatste decennia heeft voltrokken in de financiële structuur van het Nederlandse bedrijfs. leven. Zoals de cijfers in de volgende paragraaf aantonen zijn de rollen van het eigen vermogen en het vreemde vermogen welhaast omgekeerd. zijn:

Er zijn meerdere oorzaken voor dit verschijnsel aan te wijzen. De belangrijkste

- de absolute en relatieve stijging van de arbeidskosten

- de technologische ontwikkeling

- de inflatie.

Het is de bedoeling van dit artikel nader in te gaan op de rol van de laatstge. noemde. Alvorens dit te doen zal de omvang van de structurele wijziging in de financiële verhoudingen worden besproken (par. 2) en zal enige aandacht worden geschonken aan de twee eerstgenoemde oorzaken (par. 3 en par. 4), dit, omdat bedacht dient te worden dat het vooral het gezamenlijke optreden van alle ge. noemde faktoren is wat het zo opvallende verschijnsel heeft veroorzaakt.

\section{De financiële structuur van het Nederlandse bedrijfsleven}

In tabel 1 ziet men de ontwikkeling van de vermogensverhoudingen van alle $\mathrm{Ne}$. derlandse beurs.N.V.'s gedurende de afgelopen 28 jaren, gespecificeerd voor 25 bedrijfstakken en voor geheel Nederland. De tabel geeft het vreemde vermogen als percentage van het totale vermogen (VV/TV - 100\%). Tabel 2 geeft voor de zelfde periode voor geheel Nederland de verhouding vreemd/eigen vermogen (VV/EV $\cdot 100 \%)$.

I) Deel II van dit artikel zal verschijnen in: december 1977 
Bedr.

tak: Jaar:

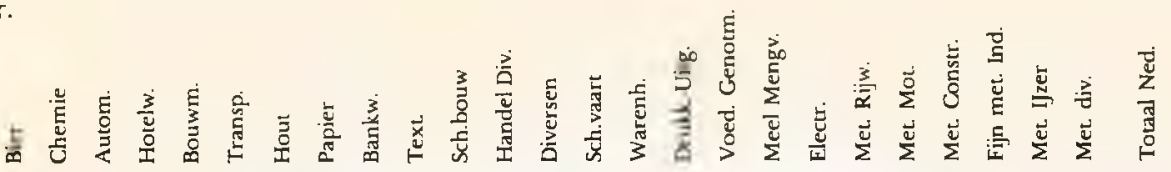

$\begin{array}{lllllllllllllllllllllllllll}1948 & 45 & 47 & 40 & 42 & 61 & 42 & 44 & 46 & 93 & 35 & 84 & 59 & 20 & 47 & 36 & 42 & 51 & 47 & 44 & 30 & 71 & 75 & 41 & 39 & 50 & 66\end{array}$ $\begin{array}{lllllllllllllllllllllllllllll}1949 & 44 & 46 & 31 & 41 & 66 & 43 & 48 & 47 & 93 & 39 & 86 & 64 & 26 & 47 & 42 & 49 & 57 & 53 & 50 & 32 & 70 & 79 & 57 & 34 & 50 & 68\end{array}$ $\begin{array}{lllllllllllllllllllllllllll}1950 & 46 & 47 & 31 & 38 & 65 & 38 & 52 & 54 & 92 & 44 & 84 & 59 & 25 & 44 & 50 & 48 & 58 & 55 & 60 & 14 & 71 & 80 & 60 & 37 & 54 & 66\end{array}$ $\begin{array}{llllllllllllllllllllllllllll}1951 & 43 & 50 & 37 & 38 & 72 & 36 & 53 & 59 & 93 & 51 & 86 & 63 & 27 & 43 & 49 & 54 & 59 & 53 & 48 & 15 & 69 & 83 & 60 & 47 & 56 & 66\end{array}$ $\begin{array}{lllllllllllllllllllllllllll}1952 & 44 & 49 & 27 & 39 & 68 & 32 & 46 & 41 & 93 & 49 & 88 & 59 & 25 & 41 & 47 & 43 & 54 & 48 & 50 & 30 & 63 & 83 & 57 & 48 & 54 & 66\end{array}$ $\begin{array}{lllllllllllllllllllllllllll}1953 & 42 & 48 & 40 & 39 & 72 & 36 & 47 & 43 & 93 & 48 & 88 & 59 & 18 & 38 & 47 & 49 & 57 & 47 & 51 & 29 & 62 & 81 & 52 & 44 & 55 & 65\end{array}$ $\begin{array}{lllllllllllllllllllllllllll}1954 & 49 & 46 & 43 & 36 & 78 & 24 & 55 & 39 & 92 & 41 & 88 & 59 & 21 & 39 & 50 & 48 & 53 & 47 & 51 & 49 & 63 & 81 & 55 & 40 & 56 & 65\end{array}$ $\begin{array}{lllllllllllllllllllllllllll}\left.1955^{*}\right) & 50 & 47 & 50 & 39 & 78 & 22 & 56 & 38 & 93 & 39 & 87 & 58 & 6 & 44 & 52 & 55 & 49 & 45 & 47 & 53 & 65 & 80 & 65 & 45 & 54 & 52\end{array}$ $\begin{array}{llllllllllllllllllllllllllll}1956 & 46 & 48 & 62 & 37 & 82 & 19 & 53 & 39 & 93 & 39 & 84 & 60 & 7 & 42 & 55 & 56 & 49 & 46 & 52 & 51 & 63 & 78 & 65 & 38 & 54 & 55\end{array}$ $\begin{array}{llllllllllllllllllllllllllll}1957 & 49 & 48 & 62 & 37 & 84 & 21 & 53 & 41 & 92 & 39 & 83 & 59 & 4 & 42 & 59 & 54 & 47 & 59 & 54 & 53 & 55 & 75 & 67 & 34 & 52 & 54\end{array}$ $\begin{array}{lllllllllllllllllllllllllll}1958 & 49 & 47 & 44 & 49 & 85 & 23 & 46 & 38 & 93 & 38 & 84 & 57 & 4 & 39 & 56 & 55 & 41 & 55 & 52 & 51 & 55 & 74 & 61 & 37 & 51 & 46\end{array}$ $\begin{array}{lllllllllllllllllllllllllll}1959 & 48 & 44 & 49 & 45 & 86 & 24 & 46 & 34 & 93 & 35 & 82 & 59 & 4 & 37 & 58 & 51 & 40 & 49 & 51 & 54 & 58 & 73 & 51 & 37 & 48 & 44\end{array}$ $\begin{array}{lllllllllllllllllllllllllll}1960 & 47 & 42 & 47 & 39 & 84 & 29 & 53 & 37 & 93 & 40 & 78 & 61 & 4 & 36 & 58 & 54 & 41 & 44 & 53 & 53 & 62 & 72 & 51 & 33 & 51 & 45\end{array}$ $\begin{array}{llllllllllllllllllllllllllll}1961 & 45 & 40 & 44 & 36 & 84 & 31 & 51 & 37 & 93 & 40 & 76 & 62 & 4 & 35 & 61 & 54 & 42 & 44 & 55 & 54 & 59 & 69 & 57 & 30 & 50 & 46\end{array}$ $\begin{array}{lllllllllllllllllllllllllll}1962 & 44 & 39 & 41 & 35 & 82 & 32 & 50 & 40 & 93 & 41 & 70 & 61 & 4 & 34 & 61 & 59 & 43 & 48 & 50 & 50 & 57 & 72 & 51 & 30 & 52 & 45\end{array}$ $\begin{array}{llllllllllllllllllllllllllll}1963 & 47 & 40 & 47 & 39 & 79 & 36 & 52 & 42 & 93 & 36 & 70 & 63 & 7 & 34 & 62 & 55 & 45 & 57 & 50 & 52 & 47 & 73 & 52 & 29 & 49 & 47\end{array}$ $\begin{array}{llllllllllllllllllllllllllll}1964 & 47 & 40 & 52 & 38 & 80 & 37 & 55 & 42 & 94 & 42 & 70 & 64 & 6 & 36 & 60 & 54 & 47 & 50 & 51 & 44 & 49 & 74 & 44 & 41 & 46 & 49\end{array}$ $\begin{array}{llllllllllllllllllllllllllll}1965 & 47 & 46 & 53 & 34 & 78 & 36 & 57 & 43 & 94 & 39 & 74 & 64 & 6 & 39 & 59 & 48 & 46 & 49 & 53 & 46 & 53 & 68 & 45 & 39 & 43 & 50\end{array}$ $\begin{array}{lllllllllllllllllllllllllllll}1966 & 47 & 48 & 50 & 54 & 79 & 38 & 56 & 43 & 95 & 38 & 69 & 64 & 5 & 39 & 62 & 48 & 46 & 55 & 55 & 62 & 52 & 69 & 43 & 43 & 44 & 51\end{array}$ $\begin{array}{llllllllllllllllllllllllllll}1967 & 49 & 46 & 52 & 51 & 78 & 39 & 55 & 47 & 95 & 38 & 69 & 65 & 6 & 40 & 64 & 49 & 47 & 56 & 56 & 58 & 43 & 70 & 44 & 45 & 53 & 53\end{array}$ $\begin{array}{llllllllllllllllllllllllllll}1968 & 46 & 47 & 53 & 65 & 75 & 69 & 56 & 48 & 95 & 38 & 70 & 66 & 7 & 42 & 63 & 52 & 46 & 58 & 57 & 57 & 43 & 73 & 52 & 44 & 44 & 55\end{array}$ $\begin{array}{lllllllllllllllllllllllllll}1969 & 52 & 55 & 60 & 55 & 73 & 72 & 60 & 49 & 96 & 57 & 74 & 67 & 8 & 44 & 65 & 52 & 46 & 59 & 59 & 66 & 55 & 74 & 61 & 48 & 48 & 60\end{array}$ $\begin{array}{lllllllllllllllllllllllllll}1970 & 53 & 56 & 62 & 52 & 77 & 74 & 62 & 55 & 97 & 61 & 77 & 66 & 7 & 36 & 64 & 54 & 53 & 62 & 63 & 56 & 55 & 69 & 65 & 50 & 51 & 63\end{array}$ $\begin{array}{lllllllllllllllllllllllllll}1971 & 50 & 56 & 59 & 52 & 78 & 75 & 59 & 60 & 96 & 59 & 84 & 64 & 9 & 37 & 63 & 55 & 54 & 59 & 64 & 58 & 56 & 68 & 75 & 53 & 52 & 65\end{array}$ $\begin{array}{lllllllllllllllllllllllllll}1972 & 54 & 56 & 61 & 60 & 78 & 78 & 61 & 63 & 96 & 57 & 83 & 69 & 13 & 51 & 65 & 58 & 50 & 57 & 62 & 48 & 54 & 68 & 74 & 40 & 57 & 63\end{array}$ $\begin{array}{llllllllllllllllllllllllllllll}1973 & 55 & 56 & 66 & 38 & 79 & 82 & 65 & 63 & 97 & 58 & 83 & 72 & 16 & 55 & 68 & 61 & 51 & 67 & 61 & 49 & 55 & 67 & 74 & 37 & 67 & 71\end{array}$ $\begin{array}{llllllllllllllllllllllllllll}1974 & 54 & 59 & 71 & 42 & 82 & 84 & 69 & 63 & 97 & 59 & 84 & 72 & 16 & 93 & 69 & 62 & 57 & 71 & 63 & 53 & 55 & 67 & 73 & 34 & 71 & 75\end{array}$ $\begin{array}{lllllllllllllllllllllllllll}1975 & 56 & 62 & 71 & 40 & 77 & 68 & 64 & 97 & 61 & 84 & 71 & 18 & 60 & 71 & 64 & 57 & 69 & 63 & 54 & 55 & 71 & 76 & 31 & 66 & 73\end{array}$

Tabel 1: vreemd vermogen als \% van totaal vermogen voor 25 bedriffstakken en geheel $\mathrm{Ne}$ derland, 1948-1975.

\footnotetext{
9) De opvallende sprong in de bedrijfstak ..Diversen” wordt veroorzaakt doordat de Koninklijke Olie in dat jaar op een andere wasrdering van de post Deelnemingen overging.
} 


\begin{tabular}{llll}
\hline jaar & VV/EV & jaar & VV/EV \\
\hline 1948 & 194 & 1962 & 82 \\
1949 & 213 & 1963 & 89 \\
1950 & 194 & 1964 & 96 \\
1951 & 194 & 1965 & 100 \\
1952 & 194 & 1966 & 104 \\
1953 & 186 & 1967 & 113 \\
1954 & 186 & 1968 & 122 \\
1955 & 108 & 1969 & 150 \\
1956 & 122 & 1970 & 170 \\
1957 & 117 & 1971 & 186 \\
1958 & 85 & 1972 & 170 \\
1959 & 79 & 1973 & 245 \\
1960 & 82 & 1974 & 300 \\
1961 & 85 & 1975 & 270 \\
\hline
\end{tabular}

Tabel 2: vreemd/eigen vermogen in \%, geheel Nederland, 1948-1975.

\section{Toelichting bij de berekende vermogensyerhoudingen}

De vermogensverhoudingen werden berekend op basis van de vermogensvormen zoals die werden gepresenteerd in 8.144 jaarverslagen van 409 Nederlandse ondernemingen waarvan en voorzover de aandelen in een periode van 28 jaar, van 1 januari $1948 \mathrm{t} / \mathrm{m} 31$ december 1975, werden genoteerd aan de Amsterdamse effectenbeurs. $\left.{ }^{2}\right)$ Dit betreft het geheel van de genoteerde Nederlandse ondernemingen met uitzondering van de cultures, de verzekeringsmaatschappijen, de hypotheekbanken, de beleggingsmaatschappijen en een luchtvaartmaatschappij. Uit het voorgaande volgt dat de ontwikkeling in de vermogensverhoudingen is beinvloed o.a. door nieuwe introducties, door liquidatie en door overneming van ondernemingen waarvan de aandelen niet als Nederlands aandeel aan de genoemde beurs werden genoteerd. Van de onderneming Unilever werden alleen de gegevens van de Nederlandse tak in het onderzoek verwerkt en van de Kon. Ned. Petroleum Maatschappij werden de gegevens van deze onderneming als hol. ding maatschappij opgenomen. De rubricering van de data vond plaats op basis van geconsolideerde gegevens indien en voorzover van enig jaar zowel de geconsolideerde balans als de geconsolideerde resultatenrekening in het jaarverslag waren opgenomen. In de andere gevallen werden de gegevens ontleend aan de jaarrekening van de moedermaatschappij. Steeds werd uitgegaan van tot na (voorgestelde) winstverdeling herleide balansen per het einde van het kalenderjaar.

\footnotetext{
3eze cijfers werden tesamen met vele andere door en onder leiding van - Drs. A. Schoorlemmer verzameld t.b.v. een onderzoek naar de relatie van de rentabiliteit, de investeringen en de financiering met het aandelengedrag van Nederlandse on dernemingen. De resultaten van dit onderzoek zullen t.z.t. elders worden gepubliceerd. Assistentie bij de rangschikking van de gegevens werd verleend door Mevr. M. Smulders.van Erp. Het programma voor het opslaan en bewerken van de data werd geschreven door H. Mulders, medewerker rekencentrum KHI.
} 
De gegevens van ondernemingen waarvan het boekjaar niet samenvalt met het kalenderjaar werden toegerekend aan het kalenderjaar waarvan het grootste deel van het boekjaar onderdeel vormt.

Naast de algemeen aanvaarde normen van eigen vermogen werden onder het eigen vermogen opgenomen de herwaarderingsreserve van het als minderheidsbelang van derden in geconsolideerde meerderheidsdeelnemingen permanent beschikbare vermogen. Bovendien is aangenomen dat in geval van toekenning van een keuzedividend, door de aandeelhouders steeds werd gekozen voor de „uitkering" in de vorm van aandelen. Naast de algemeen aanvaarde vormen van vreemd vermogen werden tot het vreemde vermogen gerekend de voorziening voor latente belastingverplichtingen en de overige voorzieningen op lange en op korte termijn. Waar in de jaarverslagen aan het begrip reserve een zeer uiteen. lopende inhoud wordt gegeven is getracht om op basis van de toelichtingen een theoretisch verantwoorde toerekening van de desbetreffende vermogensvormen aan echte reserves en aan voorzieningen tot stand te brengen. Daarbij is als uitgangspunt gekozen de volgende definitie voor het begrip voorzieningen. Voorzieningen zijn bestanddelen van het beschikbare vermogen die primair als functie hebben de dekking van specifieke aanwijsbare bedrijfsrisico's en of verplichtingen waarvan de omvang en/of het tijdstip van realisering niet precies vaststaan. Reserves ter dekking van algemene ondernemingsrisico's en reserves met primair een bijzondere financieringsfunctie werden als echte reserves en dus als een vorm van eigen vermogen aangemerkt. Naast de voorzieningen werden ook de (achtergestelde) in aandelen converteerbare obligatieleningen gerangschikt onder het vreemde vermogen. De indeling van de ondernemingen naar bedrijfstak. ken die noodzakelijk van beperkte betekenis is, vond plaats volgens criteria die als een „compromis" van de daarvoor in de literatuur en in de praktijk voorkomende richtlijnen kunnen worden aangemerkt. Uitgangspunt is daarbij geweest de aard van het oorspronkelijke hoofdbedrijf van de onderneming.

Op het eerste gezicht vallen in tabel 1 onmiddellijk de verschillen tussen de bedrijfstakken op (horizontaal). Deze verschillen zijn te verklaren uit de aard van de bedrijfsvoering (bijv. banken) en/of uit financieringsgewoonten (bijv. afnemers. krediet bij scheepsbouw en bouwnijverheid). Ook incidentele omstandigheden kunnen een rol spelen, zoals in het geval van de bedrijfstak „Diversen”, welke door de Koninklijke Olie holding wordt gedomineerd, welke zoals bekend vnl. met eigen vermogen is gefinancierd.

Volgen we de bedrijfstakken in de tijd (verticaal), dan blijkt dat alle eenzelfde patroon vertonen, dat ruwweg als volgt kan worden geschetst. In de 10 jaren na de oorlog werd door het bedrijfsleven - noodgedwongen - relatief veel gebruik gemaakt van vreemd vermogen. Daarna komt een iets kortere periode gekenmerkt door aandelenemissies en vooral door sterke winstinhouding. Daardoor zakt het aandeel van het vreemde vermogen in het totaal. Vanaf ongeveer 1962 neemt het vreemde vermogen relatief weer toe, aanvankelijk geleidelijk, de laatste jaren in een steeds sneller tempo.

Deze tendentie blijkt (uiteraard) nog sterker in tabel 2. Steeg de verhouding vreemd/ eigen vermogen voor geheel Nederland in de eerste zeven jaren na 1962 van 0,8 naar 1,2 , in de tweede zeven jaren groeide deze verhouding van 1,2 naar 2,7 ! 




Fig. 1: Bepaling optimale levensduur

\section{De groei van de arbeidskosten}

De toename van de arbeidskosten veroorzaakt een groei in de vermogensbehoefte van ondernemingen. Om de werking van dit proces te verduidelijken kan gebruik worden gemaakt van de volgende figuur (fig. 1) welke in enigszins aange. paste vorm weergeeft de uit de literatuur bekende simultane bepaling van de op. timale levensduur van een duurzaam produktiemiddel, bijv. een machine, en de kostprijs van het met behulp van die machine voortgebrachte produkt.

De horizontale as van de figuur geeft aan de mogelijke waarden die de vooralsnog onbekende levensduur van de machine kan aannemen, $q$, gemeten in een. heden voort te brengen produkt.

De curve $k_{m}$ geeft de gemiddelde machinekosten, (afschrijvingen) per eenheid produkt, als funktie van de levensduur q.

De curve $\mathrm{k}_{\mathrm{c}}$ geeft de gemiddelde complementaire kosten, dit zijn de overige met de machine verbonden kosten (voornamelijk van arbeid) per eenheid produkt, eveneens als funktie van $\mathrm{q}$.

De curve $k_{t}$ tenslotte geeft de gemiddelde totale kosten, de optelsom van $k_{m}$ en $k_{c}$, dus evenzo een functie van $q$.

Zoals in de figuur is te zien heeft $\mathrm{k}_{\mathrm{m}}$ een hyperbolisch verloop omdat, indien 
de machine langer wordt gehouden, de - constante - aanschaffingsprijs van de machine over meer produkten kan worden uitgesmeerd waardoor de afschrijvingskosten per produkt asymptotisch dalen.

Voor wat $k_{c}$ betreft is aangenomen dat het langer aanhouden van de machine lineair-stijgende complementaire kosten per eenheid produkt ten gevolge heeft.

De levensduur van de machine is optimaal bij een waarde $q=q^{*}$, als de gemiddelde totale kosten minimaal zijn $\left.{ }^{3}\right)$. De waarde $k_{t}=k_{t}^{\text {ik }}$ waarvoor dit het geval is kan men ook de kostprijs van het produkt noemen. Het vorenstaande kan ook iets anders worden geformuleerd. De optimale levensduur van de machine is duidelijk voorbij zodra de marginale complementaire kosten - de complementaire kosten van het laatst voortgebrachte produkt - de kostprijs van het produkt gaan overtreffen. De resterende werkeenheden van de machine hebben dan voor het bedrijf in deze aanwending geen waarde meer: het bedrijf kan beter een nieuwe machine aanschaffen. De marginale complementaire kosten verlopen volgens $\left.\mathrm{k}_{\mathrm{c}}{ }^{4}{ }^{4}\right)$ Op het punt waar $\mathrm{k}_{\mathrm{c}}^{\prime}$ gelijk wordt aan $\mathrm{k}_{\mathrm{t}}^{\mathrm{k}}$. - en dit is het geval voor $\mathrm{q}=0 \mathrm{D}$, is de optimale levensduur verstreken.

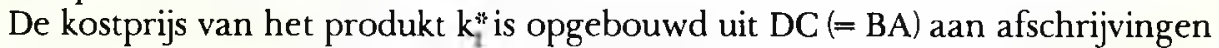
(systeem: vast percentage aanschafwaarde) en $\mathrm{DB}(=\mathrm{CA})$ aan complementaire kos. ten.

Indien de aanschaffingsprijs van de machine én de complementaire kosten (lees arbeidskosten) gelijk snel stijgen dan stijgt weliswaar de kostprijs van het produkt maar de optimale levensduur blijft ongewijzigd ${ }^{5}$ ). Dit is in fig. 1 aan te geven door de bedragen van de verticale as met het prijsstijgingspercentage te vermeerderen. Stijgen de arbeidskosten relatief het snelst, dan krijgen we de situatie zoals geschetst in fig. 2: de complementaire kosten curve gaat steiler verlopen, $\mathrm{k}_{\mathrm{cl}}, \mathrm{k}_{\mathrm{cl}}^{\prime}$ en $\mathrm{k}_{\mathrm{t} 1}$ hebben een grotere hellingshoek dan $\mathrm{k}_{\mathrm{c}}$, $\mathrm{k}_{\mathrm{c}}^{\prime}$ en $\mathrm{k}_{\mathrm{t}}$. Het gevolg is dat de optimale levensduur daalt van $\mathrm{q}^{*}$ naar $\mathrm{q}_{1}^{*}$ zodat de bestaande machines sneller zul len worden vervangen dan oorspronkelijk door de onderneming was gepland. Tevens stijgt de kostprijs van de voortgebrachte produkten van $k_{1}^{*}$ naar $k_{t 1}^{* *}$. Voor. zover de onderneming er niet in slaagt de opbrengst van de produkten evenredig te verhogen - dus de kostenstijging volledig af te wentelen op de afnemers, hier. over later meer - daalt de winstmarge en de periodewinst. Omdat de bestaande machines sneller worden vervangen dan gepland, zullen de gecumuleerde af. schrijvingen niet voldoende vermogen hebben opgeleverd om er de aanschaf.

\footnotetext{
${ }^{3} \mathrm{q}^{*}$ is op de bekende wijze te vinden door $\mathrm{k}_{l}$ te differentiëren naar $q$ en $\mathrm{dk}_{l} / \mathrm{d}_{\mathrm{q}}$ gelijk te stellen aan 0 . Bij het boven beschreven verloop der curven is

$k_{1}=k_{m}+k_{c}=M / q+N q+0$, waarin

$\mathrm{M}, \mathrm{N}$ en 0 positieve constanten zijn.

$\mathrm{dk}_{\mathrm{r}} / \mathrm{d}_{\mathrm{q}}=-\mathrm{M} / \mathrm{q}^{2}+\mathrm{N}=0$.

Hieruit volgt $q^{* \prime}=\sqrt{M / N}$ en $k_{i}^{*}=2 \sqrt{M N}+0$. Bijv.: is $M=25, N=1 / 4$ en $0=2$, dan is $q^{*}=10$ en $k_{i}^{n}=7$. Omdat $d^{2} k_{q} / d_{q} 2$

$=2 \mathrm{M} / \mathrm{q}^{3}>0$, is inderdaad sprake van een kostenminimum.

4) De relatie tussen de gemiddelde complementaire kosten en de marginale complementaire kosten is als volgt:

$\mathrm{k}_{\mathrm{c}}^{\prime}=\mathrm{d}\left(\mathrm{k}_{\mathrm{c}} \cdot \mathrm{q}\right) / \mathrm{d}_{\mathrm{q}}$. Heeft $\mathrm{k}_{\mathrm{c}}$ de aangegeven lineaire vorm:

$\mathrm{k}_{\mathrm{c}}=\mathrm{Nq}+0$, dan is

$k_{c}^{\prime}=d\left(\mathrm{Nq}^{2}+0 \mathrm{q}\right) / \mathrm{d}_{\mathrm{q}}=2 \mathrm{Nq}+0$. D.w.z. $\mathrm{k}_{\mathrm{c}}$ en $\mathrm{k}_{\mathrm{c}}^{\prime}$ starten in hetzelfde punt maar de helling van $\mathrm{k}_{\mathrm{c}}^{\prime}$ is twee keer zo groot als die van $k_{c}$.

5) Hierover méér in par. 5
} 


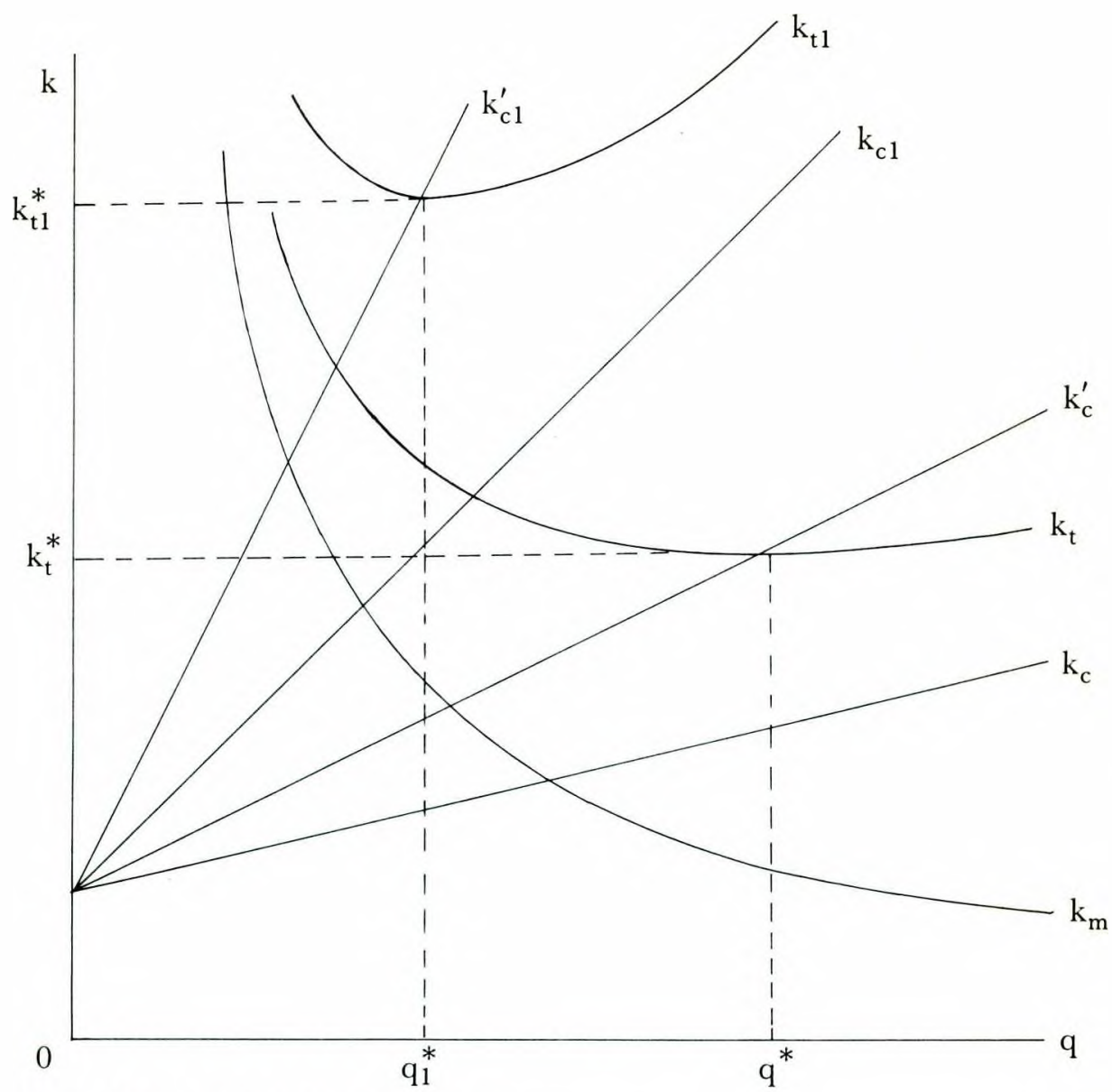

Fig. 2: Effect van stijging arbeidskosten

fingsprijs van de nieuwe machine mee te financieren. $\left.{ }^{6}\right)$. De onderneming heeft om in dezelfde omvang te continueren dus extra vermogen nodig. Door de dalende rentabiliteit zal het moeilijk zijn intern of extern eigen vermogen te gene reren, zodat de onderneming gedwongen wordt vreemd vermogen aan te trek. ken met het in par. 2 beschreven gevolg.

\footnotetext{
6) Stel, om de gedachten te bepalen, dat $k_{c l}=N_{1} q+0=q+2$. Dan is qu gelijk aan $\sqrt{25}=5$ en $k_{11}^{*}$ is $2 \cdot \sqrt{25}+2=12$. Doet de arbeidskostenstijging zich voor als de machine bijvoorbeeld 4 jaren oud is, en wordt de machine lineair afgeschreven dan is op dat moment afgeschreven

$4 \times \frac{13}{1}=10$. Gedurende hel vijde jaar kan bij volledige afwenteling worden afgeschreven $\frac{25}{2}=5$. Aan het eind van jaar 5 moet de machine worden vervangen. Bij gelijkblijvende aanschafprijs van de machine moet extra vermoger worden aangetrokken ten bedrage van $25-(10+5)=10$ Wil men de afschrijvingen gelijk stellen aan de feitelijke waardedaling van de voorraad werk eenheden zoals uit theoretisch gezichispunt de voorkeur verdient maar wat niet lineaire afschrijvingen impliceert - dan moeten de periodieke afschrijvingen worden bepaald als het verschil tussen de integrale totale kosten en de integrale complementaire kosten. In het vervolg van dit artikel zal steeds met lineaire afschrijvingen worden gewerkt.
} 


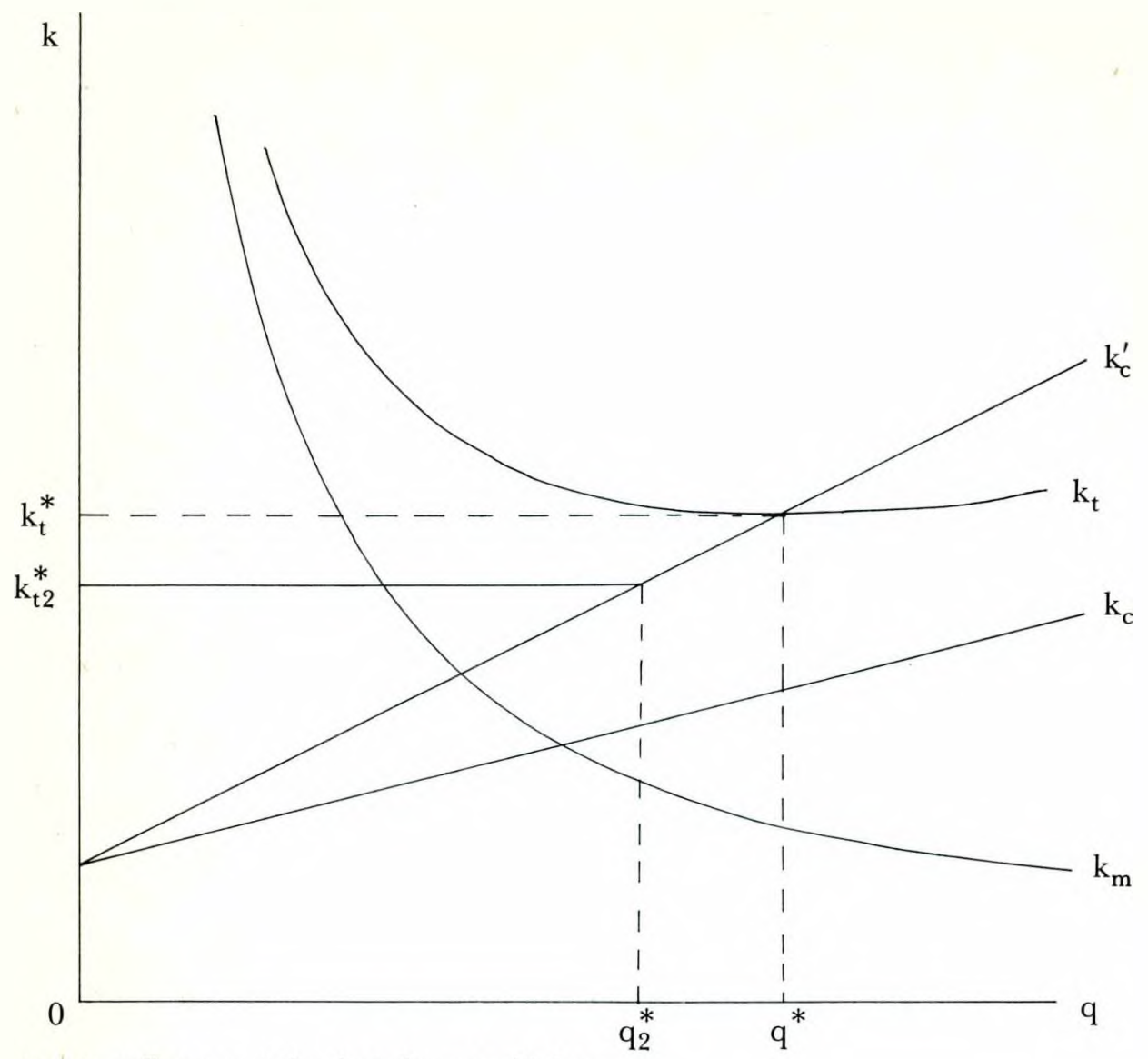

Fig. 3: Effect van technologische ontwikkeling

\section{De technologische ontwikkeling}

Figuur 1 kan ook worden gebruikt om de invloed van de technologische ontwik. keling op de vermogensbehoefte van de onderneming weer te geven. Stel een onderneming produceert met de machine in kwestie onder de condities zoals ge. schetst in fig. 1, welke zijn herhaald in fig. 3. Tengevolge van de vooruitgang in de kennis van de techniek komen nieuwe machines aan de markt die superieur zijn t.o.v. de bestaande machines, in die zin dat een grotere prestatie wordt geleverd tegen dezelfde kosten per periode of een gelijke prestatie tegen lagere kosten per periode of beide. In alle gevallen is het resultaat een lagere kostprijs van het produkt van de nieuwe machine t.o.v. die van de bestaande machine. De nieuwe machines hebben vaak een hogere aanschafprijs dan de bestaande doch nodig is dit niet. De ondernemingen zullen de aanwezige machines afschaffen zodra de marginale complementaire kosten van de bestaande machines hoger dreigen te worden dan de kostprijs van het produkt gemaakt op een nieuwe machine (de laatste omvat uiteraard afschrijving en vermogenskosten van de nieuwe machi. ne). Zijn, zoals wij hebben aangenomen, de marginale complementaire kosten een toenemende funktie van de leeftijd van de machine dan betekent de lagere 
kostprijs van de nieuwe machine onherroepelijk een verlaging van de levensduur van de bestaande. Is in fig. 3 de kostprijs van het produkt van de nieuwe machine bijv. $\mathrm{k}_{\mathrm{t} 2}$, dan daalt de optimale levensduur van de bestaande machine van $\mathrm{q}^{\text {*k }}$ naar

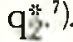

Het hangt van meerdere faktoren af hoe groot de extra vermogensbehoefte, veroorzaakt door de eerdere buitengebruikstelling van de bestaande machine, zal zijn. Genoemd kunnen worden - naast de aanschafprijs van de nieuwe machine en de direkte opbrengstwaarde van de bestaande - het relatieve tijdstip binnen de levensduur waarop de technologische vernieuwing zich voordoet en de mate waarin een afwenteling van de hogere afschrijvingen in de resterende jaren van de gedaalde levensduur in de vorm van een hogere kostprijs en een hogere op. brengstprijs · én wellicht een compensatie van de te lage afschrijvingen in het verleden uit de (evt. veranderde) winstmarge - mogelijk is. Deze faktoren zullen in het volgende opnieuw aan de orde komen.

\section{De inflatie}

Het bijzondere van de ,ideaaltypische” inflatie is dat alle prijzen omhoog gaan en wel met hetzelfde percentage. Zoals reeds eerder werd opgemerkt, blijkt uit de gebruikte figuren dat dan wel de kostprijs van de voortgebrachte produkten stijgt maar dat de algemene prijsstijging op zich niet leidt tot een veranderde economische levensduur van de duurzame activa. Deze uitspraak geldt voor nieuwe activa maar ook voor de bestaande, indien we althans mogen aannemen dat on dernemingen bij (kost-prijsbepaling en bij vervangingsbeslissingen de afschrijvingskosten van de aanwezige activa baseren op de prijzen van nieuwe activa. Vooralsnog zullen we van deze veronderstelling uitgaan. Dit alles betekent dat de hogere vermogensbehoefte die ondernemingen in periodes van inflatie ervaren, in tegenstelling tot wat het geval was bij stijgende arbeidskosten en techniekver. betering, niet het gevolg is van een dalende levensduur van de activa maar van de stijgende vervangingsprijzen daarvan.

De omvang van de extra vermogensbehoefte wordt door meerdere faktoren beïnvloed. Met behulp van de tot nu toe gebruikte figuren kunnen allereerst de volgende worden genoemd.

la) De aard van de prijsstijging. Hiermee wordt gedoeld op o.a. de volgende vra gen. Treft de prijsstijging alle activa of slechts bepaalde; is de prijsstijging een malig of periodiek; in dat laatste geval: zijn de percentages prijsstijging constant, toenemend of afnemend; en natuurlijk:

1b) hoe hoog is het (gemiddelde) percentage prijsstijging.

2) Het relatieve tijdstip van de prijsstijging. Bedoeld wordt de vraag of de prijsstij. ging pas aangeschafte activa betreft of activa waarvan de levensduur gedeel telijk of grotendeels reeds is verstreken. Deze vraag is alleen eenduidig te be antwoorden bij eenmalige prijsstijgingen die slechts één produktiemiddel be treffen. Gaat het om meerdere activa met uiteenlopende leeftijd en levens.

\footnotetext{
7) Stel $k_{12}=6$, dan is $q_{2}^{*}$ te vinden uit:

$2 \mathrm{Nq}+0=6 \rightarrow q_{2}^{*}=8$

D.w.z. de bestaande machines worden buiren gebruik gesteld zodra een gecumuleerde produkrie van 8 , in plaats van 10 , is bereikt. Dit hoeft echter niet samen te vallen met het moment van beschikbaar komen van de modernere machines.
} 


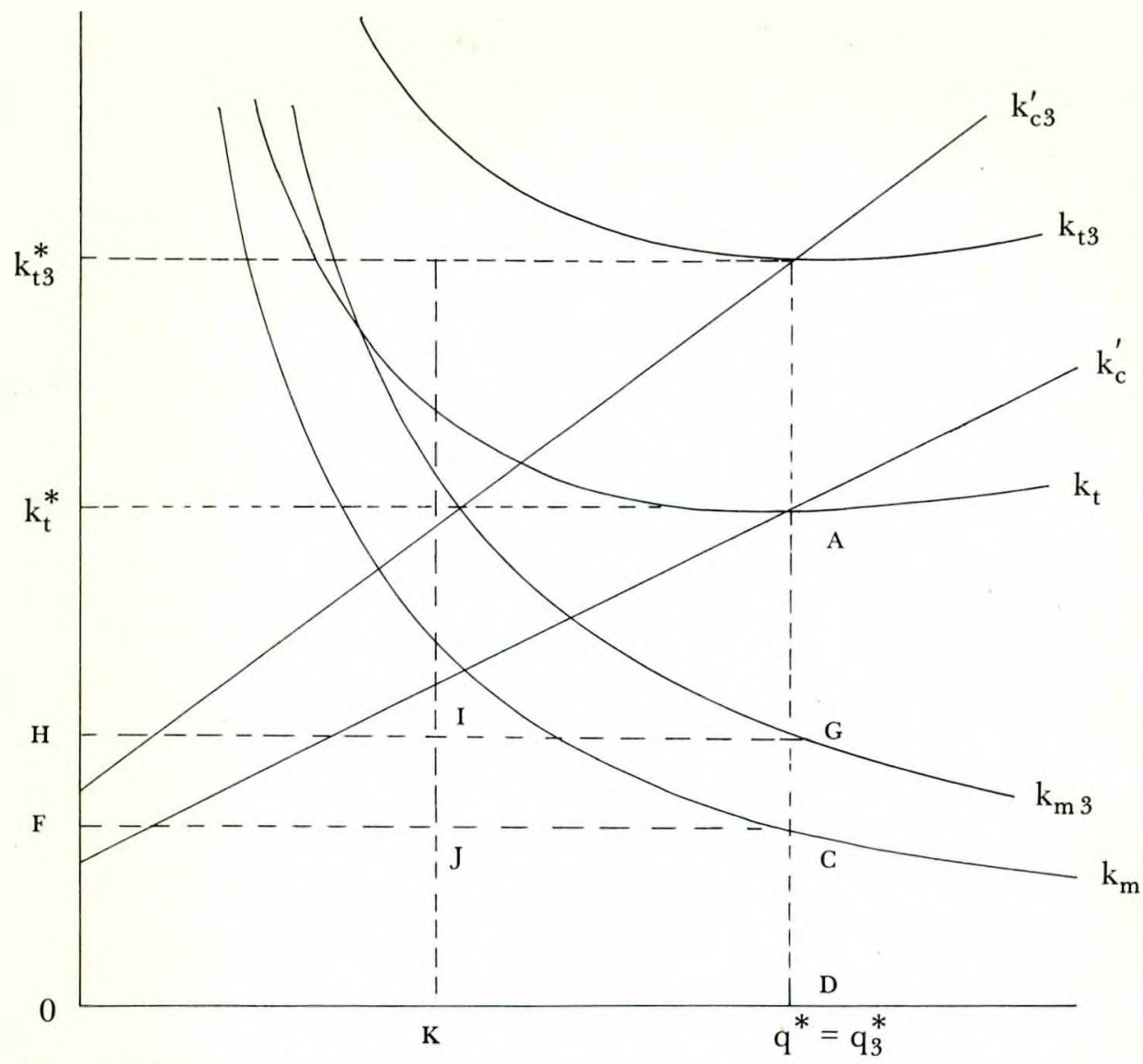

Fig. 4: Effect van algemene prijsstijging

duur en betreft het met grote frequentie optredende prijsstijgingen dan is de vraag moeilijker te beantwoorden en minder relevant.

De invloed van deze faktoren kan aan de hand van fig. 4 worden gedemonstreerd. In figuur 4 zijn getekend de gemiddelde machinekosten, de marginale complementaire kosten en de gemiddelde totale kosten, zoals eerder gedefinieerd, vóór ( $r e s p . k_{\mathrm{m}}$, $\mathrm{k}_{\mathrm{c}}^{\prime}$ en $\mathrm{k}_{\mathrm{t}}$ ) en ná $\left(\mathrm{k}_{\mathrm{m} 3}, \mathrm{k}_{\mathrm{c} 3}^{\prime}\right.$ en $\mathrm{k}_{\mathrm{t} 3}$ ) een eenmalige algemene prijsstijging. Zoals te constateren valt wordt de optimale levensduur van de machine in kwestie door de prijsstijging niet beinvloed. Wél stijgt de kostprijs van het produkt met het percentage van de prijsstijging $\left.{ }^{8}\right)$. Treedt de prijsstijging bijv. op halverwege de optimale levensduur, en berekent de onderneming vanaf dat moment de hogere kosten - en met name ook de hogere afschrijvingskosten •, via de verhoogde kostprijs van het produkt aan de afnemers door, dan komt de helft van het t.z.t. voor de vervanging van de machine extra benodigde vermogen, ge-

\footnotetext{
${ }^{8}$ ) Vervolgen we het tot nu toe gebruikte numerieke voorbeeld, en is de algemene eenmalige prijsstijging $50 \%$, dan wordt $k_{\mathrm{m} 3}=37,5 / \mathrm{q}$ en $k_{\mathrm{c} 3}=0,375 q+3$. Hieruit volgt dat

$q_{3}^{n}=\sqrt{37,5 / 0,375}=10$ en $k_{3}^{* i}=2 \sqrt{37,5 \cdot 0,375}+3=10,5$

(d.i. $50 \%$ hoger dan $\mathrm{k}$.
} 
durende de resterende jaren van de levensduur, in de vorm van verhoogde op. brengst van geproduceerde produkten, binnen. Verondersteld moet dan wel worden dat deze doorberekening ook lukt, d.w.z. dat concurrentieoverwegingen of overheidsvoorschriften niet in de weg staan. Bedacht dient tevens te worden dat de fiscus, die afschrijvingen op vervangingswaarde niet toestaat, de verhoogde af. schrijvingen als winst zal beschouwen en dus gedeeltelijk zal wegbelasten. ${ }^{9}$ )

De produkten die gedurende de eerste helft van de levensduur zijn gefabriceerd en verkocht kunnen echter niet meer in prijs worden verhoogd om de an. dere helft van de extra benodigde financieringsmiddelen te verschaffen ${ }^{10}$.

Deze middelen zullen uit de lopende winst of uit de winstreserves moeten komen, of de onderneming probeert ze de toekomstige afnemers in rekening te brengen, of er moet extern d.m.v. lenen in worden voorzien. De eerstgenoemde mogelijkheid is onzeker. Allereerst is het de vraag of de lopende winst daarvoor voldoende hoog is en of deze onveranderd zal blijven bij de gestegen kostprijs van de produkten. Ook kan deze reeds andere bestemmingen hebben. Veel hangt dus af van de hoogte en de mate van stijging van de produktprijs en van de grootte van het vermogenstekort. Dit laatste is des te groter naarmate de prijsstijging hoger is en later in de levensduur optreedt (zie fig. 4).

Behalve de faktoren: aard van de prijsstijging (1) en relatieve tijdstip van prijsstijging (2), zijn dus verder van belang:

(3) de mate waarin aanpassing van de produktprijs mogelijk is, d.w.z. afwenteling van de prijsstijging van produktiemiddelen op de afnemers plaats kan vinden, en (4) de door de onderneming gevolgde afschrijuingsmethode en de fiscale toelaatbaarheid daarvan.

Het genoemde vermogenstekort behoeft overigens niet te ontstaan indien de gecumuleerde vrijgekomen afschrijvingsgelden zodanig zijn geinvesteerd dat zij dezelfde prijsstijging meemaken als de activa waarvan zij de vervanging t.z.t. zullen moeten financieren. In termen van fig. 4 betekent dit dat op het moment van prijsstijging OKJF aangroeit met $\mathrm{FJIH}$ tot $\mathrm{OKIH}$. Als vijfde faktor die een rol speelt moet dus genoemd worden:

(5) de mate waarin de belegde afschrijvingsfondsen de inflatoire prijsstijging volgen.

Behalve deze 5 faktoren zijn er nog andere te noemen die de relatie tussen inflatie enerzijds en vermogensbehoefte en financiële structuur anderzijds beinvloe. den, zoals de samenstelling van het activacomplex en de door de onderneming zelf nagestreefde verhouding vreemd/eigen vermogen. De werking van deze andere faktoren is echter in het tot nu toe gebruikte kader van fig. 1 minder goed te analyseren. In het tweede deel van dit artikel zal daarom een andere analysemethode worden gevolgd.")

\footnotetext{
9) Vóór de prijsverhoging is het afschrijvingsaandeel in de kostprijs gelijk aan $\mathrm{DC}=\mathrm{KJ}$. Op het moment van prijssujging is dus reeds OKJF als afschrijving gecumuleerd. Bij volledige doorberekening wordr in de resterende jaren van de levensduur nog KDGI ontvangen. De belasthare verhoging van de te ontvangen afschrijvingen is dus JCGI, dit is de helft van het voor de ver vanging extra benodigde vermogen FCGH.

10) Het betreft hier F]IH in fig. 4. In het kader van de vervangingswaardetheorie beschouwt men dit vermogenstekort als verlies, veroorzaakt door te lage afschrijvingen in het verleden die alsnog een zgn.: „inhaalafschrijving” noodzaken, tenzij uit andere hoofde compensatie wordt verkregen.

11) Inflatie en de financiële structuur van ondernemingen, deel II, december 1977
} 